\title{
Eimeria minasensis n. sp. (Apicomplexa: Eimeriidae) in the Domestic Goat Capra hircus, from Brazil
}

\author{
Andréa C Silva ${ }^{+}$, José D Lima*
}

\begin{abstract}
Departamento de Parasitologia, IPTSP, Universidade Federal de Goiás, 74001-970 Goiânia, GO, Brasil
*Departamento de Parasitologia, ICB, Universidade Federal de Minas Gerais, 31270-901 Belo Horizonte,

MG, Brasil
\end{abstract}

Eimeria minasensis $n$. sp. is described in the domestic goat Capra hircus from Brazil. Oocysts ellipsoidal are $35 \times 24.5$ (32-37.7 $\times 20.9-27.9) \mathrm{mm}$. Sporocysts elongate-ellipsoid are $15.2 \times 9$ (12.3-18.4 $x$ 7.8-10.2) mm, with a Stieda body at the narrow end. Oocyst wall smooth and bilayered; outer layer about 1.2 (0.8-1.6) mm and colorless; inner layer about 0.5 (0.4-0.8) mm and dark-brown. Micropyle, a mound-shaped micropylar cap 1,6 $x$ 8,9 (0,8-2 x7-10,2) easily dislodged; one or more oocyst polar granules present. Oocyst residuum absent. Sporocyst residuum present, composed of many scattered granules. Sporozoites elongate, lying lengthwise, "head to tail" in the sporocysts; one or two refractile globules are usually visible. Sporulation time was $120 \mathrm{hr}$ at $27^{\circ} \mathrm{C}$, prepatent period, 19 to 20 days and patent period 15 to 25 days. Gamonts, gametes and oocysts present in cecum and colon. Prevalence was $12.8 \%$ (6/47) in goats from Minas Gerais, Brazil.

Key words: Eimeria minasensis n. sp. - goat - coccidia - Brazil

The number of Eimeria species considered to be parasites of the domestic goat (Capra hircus) is variable and controversial, and depends upon the acceptance of the validity of some species (Levine \& Ivens 1970, Musaev 1970, Pellérdy 1974, Lima 1979, Musaev \& Mamedova 1981, Norton 1986). Several species considered as parasites of both goat and sheep were not able to infect one or other of those hosts in cross transmission studies (Levine \& Ivens 1970, Lima 1979a). Levine (1988) listed 13 species as true parasites of goats. Later, Soe and Pomroy (1992) described three new species of Eimeria as parasites of goats in New Zealand. A new species of Eimeria from the domestic goat found in the State of Minas Gerais, Brazil, is described in this paper.

\section{MATERIALS AND METHODS}

Fecal samples of adult goats from the municipalities of Esmeraldas (15 samples) and Sete Lagoas (32 samples), State of Minas Gerais, Brazil, were examined for coccidia. Positive samples were mixed with $2.5 \%(\mathrm{w} / \mathrm{v})$ potassium dichromate $\left(\mathrm{K}_{2} \mathrm{Cr}_{2} \mathrm{O}_{7}\right)$, filtered to remove coarse debris, spread

\footnotetext{
This work was sponsored by $\mathrm{CNPq}$ and Fapemig. ${ }^{+}$Corresponding author. Fax: +55-62-202.3066. E-mail: andrea@iptsp.ufg.br

Received 28 January 1998

Accepted 13 July 1998
}

in a thin layer in covered Petri dishes and allowed to sporulate at room temperature (about $25^{\circ} \mathrm{C}$ ), for a week.

To determine some biological parameters, five goats were experimentally infected, at different times, with oocysts of the new species as described below. The goats used for these infections were separated from does immediately after birth, and raised under coccidia-free conditions, in individual cages kept in closed rooms with restricted access.

Fifty sporulated oocysts of the new species were collected with a micropipette, using a dissecting microscope, and their identity confirmed by light microscopy; and given per os to a seven-mo-old goat, in order to build up an inoculum for further experiments.

A three-mo-old kid was inoculated with $10^{5}$ sporulated oocysts obtained from the previously inoculated goat. Feces were collected daily and samples containing oocysts were allowed to sporulate as described above. After sporulation, pure cultures of oocysts of the new species were stored at $4^{\circ} \mathrm{C}$ for futher inoculations. This kid was killed 23 days after inoculation, tissues samples were fixed in $10 \%$ buffered formalin solution, embedded in paraffin, sectioned at 3-5 mm, stained with haematoxylin-eosin and examined using light microscopy to determine the site of infection.

Three, one-to-three-mo-old kids were inoculated with $10^{5}$ sporulated oocysts. To determine sporulation time, prepatent and patent periods, fecal samples were collected daily, mixed with $2.5 \%$ 
$\mathrm{K}_{2} \mathrm{Cr}_{2} \mathrm{O}_{7}$ solution, and incubated at $27^{\circ} \mathrm{C}$. Stages of sporulation were checked at $24 \mathrm{hr}$ intervals. Sporulation was considered to be completed when no additional increase in the percentage of sporulated oocysts was observed. Sporulated oocysts were examined after flotation with Sheather's sugar solution. One hundred oocysts and 100 sporocysts were measured with an ocular micrometer. All measurements are presented as mean \pm SD followed by the range in parentheses, and the shapeindex (ratio of length/width).

\section{RESULTS}

\section{Eimeria minasensis n. sp. (Figs 1-4)}

Oocysts ellipsoidal, $35 \pm 1.5(32-37.7) \mathrm{x}$ 24.5 $\pm 1.7(20.9-27.9) \mathrm{mm}$, shape-index $1.4 \pm 0.1$ (1.3-1.6). Oocyst wall smooth and bilayered; outer layer about $1.2 \pm 0.2(0.8-1.6) \mathrm{mm}$ and colorless; inner layer about $0.5 \pm 0.1(0.4-0.8) \mathrm{mm}$ and darkbrown. Micropyle present. An easily dislodged mound-shaped micropylar cap present, colorless, $1.6 \pm 0.2(0.8-2) \mathrm{mm}$ high and $8.9 \pm 0.7(7-10.2) \mathrm{mm}$ wide. One or more oocyst polar granules present, oocyst residuum absent. Sporocysts elongate-ellipsoid 15.2 $\pm 1.1(12.3-18.4) \times 9 \pm 0.5(7.8-10.2) \mathrm{mm}$, with a Stieda body at the narrow end; shape-index $1.7 \pm 0.1$ (1.3-2). Sporocyst residuum present, composed of many scattered granules. Sporozoites elongate, lying lengthwise, "head to tail" in sporocysts; they usually contain one or two refractile bodies.

Type host: Capra hircus (Linnaeus, 1758) (domestic goat).

Type locality: municipalities of Esmeraldas and Sete Lagoas counties, Minas Gerais, Brazil.
Site of infection: gametogony in cecum and colon (Figs 5, 6).

Sporulation time: $120 \mathrm{hr}$ at $27^{\circ} \mathrm{C}$.

Prepatent period: 19 to 20 days.

Patent period: 15 to 25 days.

Prevalence: oocysts found in $20 \%(3 / 15)$ and in $9.3 \%(3 / 32)$ of goat feces examined in the municipalities of Esmeraldas and Sete Lagoas, respectively.

Type-material: phototypes of oocysts deposited in the United States National Parasite Collection no. 87296.

Etymology: the name is derived from the first name of the State (Minas Gerais) where the species was found.

\section{DISCUSSION}

Among the 16 accepted species of Eimeria from goats (Levine 1988, Soe \& Pomroy 1992), E. minasensis n. sp. differs from E. alijevi, $E$. apsheronica, E. caprina, E. caprovina, E. charlestoni, and E. ninakohlyakimovae by having a micropylar cap. Of the capped species (Table), E. africiensis, E. arloingi, E. capralis, E. hirci, E. masseyensis, and E. punctata are considerably smaller than E. minasensis. E. jolchijevi is smaller than E. minasensis and has a typically urn shaped oocyst. E. christenseni and E. kocharli are larger than E. minasensis. In addition, E. arloing $i$ and $E$. christenseni, which somewhat resemble $E$. minasensis, have known life cycles with sexual stages restricted to the small intestine of the host (Sayin et al. 1980, Lima 1981), whereas gamonts, gametes and oocysts of E. minasensis were found in cecum and colon of goat.

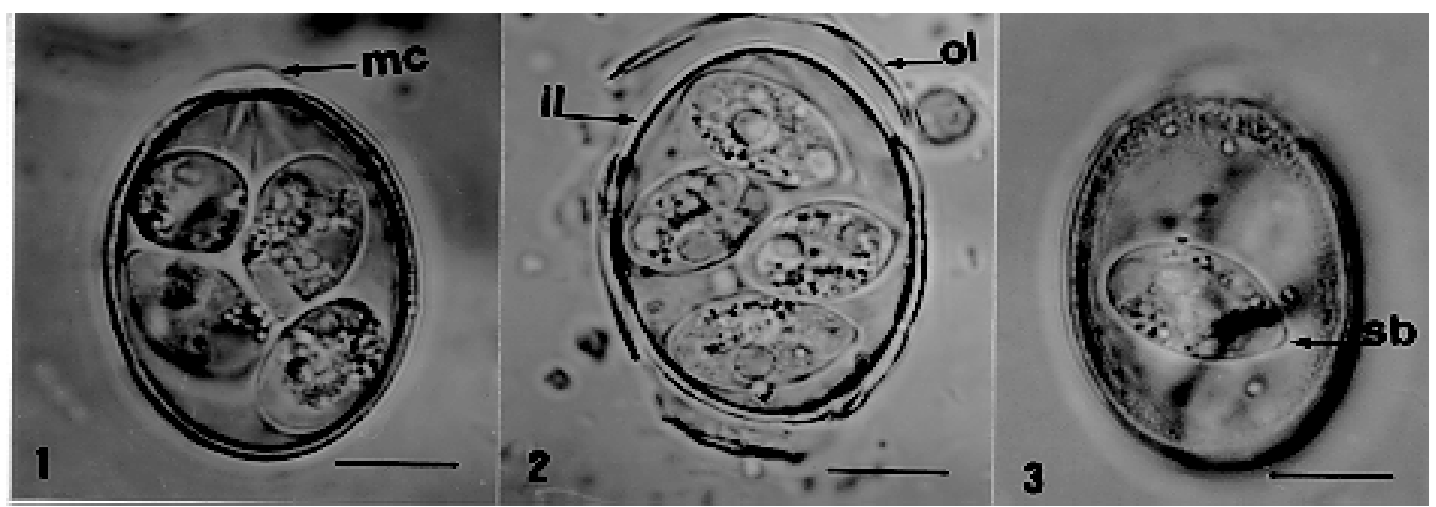

Figs 1-3: photomicrographs of sporulated oocysts of Eimeria minasensis n. sp., recovered from the feces of goats in Brazil. Bar $=10 \mathrm{~mm}$; mc: micropylar cap, ol: outer layer; il: inner layer; sb: Stieda body. 
TABLE

Measurements of oocysts and sporocysts of capped Eimeria species parasites of the domestic goat (Capra hircus)

\begin{tabular}{|c|c|c|c|c|c|c|c|c|}
\hline \multirow[b]{2}{*}{ Species } & \multirow{2}{*}{$\begin{array}{l}\text { Number } \\
\text { measured }\end{array}$} & \multirow[b]{2}{*}{ Author } & \multicolumn{3}{|c|}{ Oocyst } & \multicolumn{3}{|c|}{ Sporocyst } \\
\hline & & & Length (mm) & Width (mm) & $\mathrm{L} / \mathrm{W}$ ratio & Length (mm) & Width (mm) & $\mathrm{L} / \mathrm{W}$ ratio \\
\hline E. africiensis & 15 & Musaev \& Mamedova 1981 & $\begin{array}{c}25.63 \\
(22.0-26.0)\end{array}$ & $\begin{array}{c}20.36 \\
(18.0-22.0)\end{array}$ & $\begin{array}{c}1.2 \\
(1.1-1.3)\end{array}$ & $\begin{array}{c}17.76 \\
(12.0-18.0)\end{array}$ & $\begin{array}{c}9.03 \\
(8.0-10.0)\end{array}$ & NS \\
\hline E. arloingi & 700 & Lima 1980 & $\begin{array}{c}28.2 \pm 2.34 \\
(22.0-35.4)\end{array}$ & $\begin{array}{c}19.8 \pm 1.38 \\
(15.9-23.2)\end{array}$ & $\begin{array}{c}1.43 \pm 0.10 \\
(1.12-2.07)\end{array}$ & $\begin{array}{l}14.0 \pm 1.29 \\
(9.8-17.1)\end{array}$ & $\begin{array}{l}7.3 \pm 0.63 \\
(6.1-9.8)\end{array}$ & $\begin{array}{c}1.95 \pm 0.23 \\
(1.29-2.80)\end{array}$ \\
\hline E. capralis & 100 & Soe \& Pomroy 1992 & $\begin{array}{c}29.2 \pm 1.6 \\
(25.0-34.0)\end{array}$ & $\begin{array}{c}19.7 \pm 1.1 \\
(19.5-24.5)\end{array}$ & $\begin{array}{c}1.40 \pm 0.01 \\
(1.30-1.70)\end{array}$ & $\begin{array}{c}12.7 \pm 0.60 \\
(11.0-14.0)\end{array}$ & $\begin{array}{l}7.5 \pm 0.40 \\
(6.5-9.0)\end{array}$ & $\begin{array}{c}1.60 \pm 0.10 \\
(1.30-1.90)\end{array}$ \\
\hline E. christenseni & 200 & Lima 1980 & $\begin{array}{c}37.8 \pm 2.38 \\
(30.5-43.9)\end{array}$ & $\begin{array}{c}25.3 \pm 1.57 \\
(22.0-30.5)\end{array}$ & $\begin{array}{c}1.5 \pm 0.09 \\
(1.23-1.78)\end{array}$ & $\begin{array}{c}15.3 \pm 0.77 \\
(12.2-17.1)\end{array}$ & $\begin{array}{c}9.3 \pm 0.56 \\
(7.9-10.4)\end{array}$ & $\begin{array}{c}1.64 \pm 0.11 \\
(1.33-2.00)\end{array}$ \\
\hline E. hirci & 300 & Lima 1980 & $\begin{array}{c}22.7 \pm 2.11 \\
(18.3-29.3)\end{array}$ & $\begin{array}{c}18.1 \pm 1.16 \\
(15.9-20.7)\end{array}$ & $\begin{array}{c}1.26 \pm 0.11 \\
(1.06-1.69)\end{array}$ & $\begin{array}{l}10.9 \pm 0.93 \\
(8.5-13.4)\end{array}$ & $\begin{array}{l}7.0 \pm 0.63 \\
(5.5-8.5)\end{array}$ & $\begin{array}{c}1.58 \pm 0.19 \\
(1.14-2.10)\end{array}$ \\
\hline E. jolchijevi & 150 & Lima 1980 & $\begin{array}{c}30.6 \pm 2.04 \\
(25.5-36.6)\end{array}$ & $\begin{array}{c}22.0 \pm 1.50 \\
(18.3-25.3)\end{array}$ & $\begin{array}{c}1.40 \pm 0.10 \\
(1.19-1.67)\end{array}$ & $\begin{array}{c}14.7 \pm 1.22 \\
(12.2-17.7)\end{array}$ & $\begin{array}{l}8.0 \pm 0.62 \\
(6.1-9.8)\end{array}$ & $\begin{array}{l}1.83 \pm 0.160 \\
(1.43-2.17)\end{array}$ \\
\hline E. kocharli & NS & Vercruysse 1982 & $\begin{array}{l}45.46 \pm 2.01 \\
(41.0-50.0)\end{array}$ & $\begin{array}{l}36.67 \pm 1.01 \\
(34.0-37.0)\end{array}$ & NS & NS & NS & NS \\
\hline E. masseyensis & 100 & Soe \& Pomroy 1992 & $\begin{array}{c}22.3 \pm 1.5 \\
(18.5-25.5)\end{array}$ & $\begin{array}{c}17.3 \pm 0.9 \\
(15.0-19.5)\end{array}$ & $\begin{array}{c}1.20 \pm 0.10 \\
(1.00-1.40)\end{array}$ & $\begin{array}{c}12.1 \pm 0.80 \\
(10.0-13.5)\end{array}$ & $\begin{array}{l}6.1 \pm 0.40 \\
(5.0-7.0)\end{array}$ & $\begin{array}{c}1.90 \pm 0.10 \\
(1.60-2.50)\end{array}$ \\
\hline E. minasensis n. sp. & 100 & Present study & $\begin{array}{c}35.0 \pm 1.5 \\
(32.0-37.7)\end{array}$ & $\begin{array}{c}24.5 \pm 1.7 \\
(20.9-27.9)\end{array}$ & $\begin{array}{c}1.4 \pm 0.10 \\
(1.30-1.60)\end{array}$ & $\begin{array}{c}15.2 \pm 1.10 \\
(12.3-18.4)\end{array}$ & $\begin{array}{l}9.0 \pm 0.50 \\
(7.8-10.2)\end{array}$ & $\begin{array}{c}1.70 \pm 0.10 \\
(1.30-2.00)\end{array}$ \\
\hline E. punctata & 100 & Chevalier 1966 & $\begin{array}{c}26.1 \pm 2.2 \\
(21.4-31.3)\end{array}$ & $\begin{array}{c}19.5 \pm 1.4 \\
(15.1-22.6)\end{array}$ & 1.33 & NS & NS & NS \\
\hline
\end{tabular}

NS: not stated. 


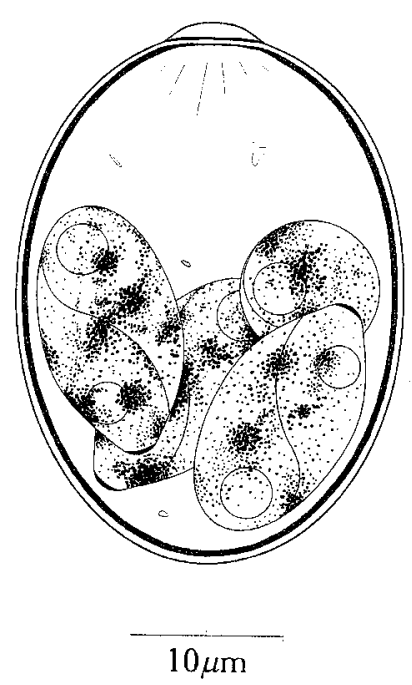

Fig. 4: Eimeria minasensis n. sp. Line drawing of a sporulated oocyst.

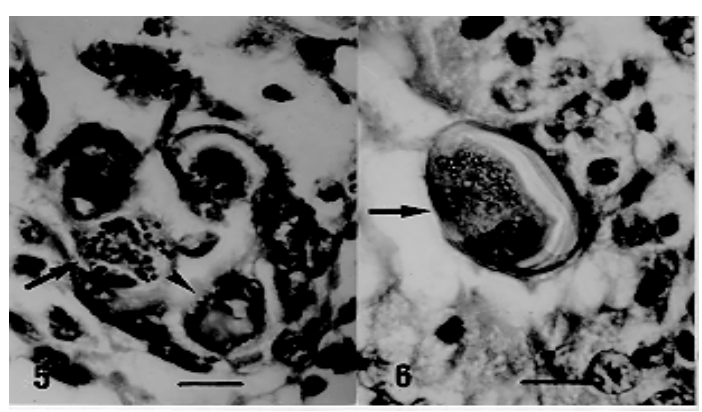

Sexual stages of Eimeria minasensis n. sp. in the cecum of the domestic goat. Fig. 5: macrogamete (arrow) and microgamont (head). Fig. 6: oocyst (arrow). Bar $=10 \mathrm{~mm}$.

\section{ACKNOWLEDGMENT}

To Mr Humberto Borém for the line drawing.

\section{REFERENCES}

Chevalier HJ 1966. Uber die Coccidienarten der Ziegen in Deutschland. Deut Tierarztl Wochenschr 73: 616621.

Levine ND 1988. The Protozoan Phylum Apicomplexa, Vol. II, CRC Press Inc., Boca Raton, 154 pp.

Levine ND, Ivens V 1970. The Coccidian Parasites (Protozoa, Sporozoa) of Ruminants, Illinois Biological Monographs 44, University of Illinois Press, Urbana, $278 \mathrm{pp}$.

Lima JD 1979. The Coccidia (Protozoa: Eimeriidae) of the Domestic Goat, Capra hircus, $\mathrm{PhD}$ Thesis, University of Illinois, Urbana, xiii + 110 pp.

Lima JD 1981. Life cycle of Eimeria christenseni Levine, Ivens \& Fritz, 1962 from the domestic goat, Capra hircus L. J Protozool 28: 59-64.

Musaev MA 1970. The host specificity of coccidia and some problems of their taxonomy. Izv Aka Nauk Azerb SSR, Ser Biol Nauk 2: 52-61.

Musaev MA, Mamedova MA 1981. Material for the taxonomy of the coccidia of the domestic goat (Capra hircus) and their structure in Azerbaijan. Izv Aka Nauk Azerb SSR, Ser Biol Nauk 4: 68-76.

Norton CC 1986. Coccidia of the domestic goat Capra hircus, with notes on Eimeria ovinoidalis and $E$. bakuensis (syn. E. ovina) from the sheep Ovis aries. Parasitology 92: 279-289.

Pellérdy LP 1974. Coccidia and Coccidiosis, 2nd ed, Paul Parey, Berlin, 959 pp.

Sayin, F, Dincer S, Milli U 1980. The life cycle and pathogenicity of Eimeria arloingi (Marotel, 1905) Martin, 1909, in Angora kids and an attempt of its transmission to lambs. Zbl Vet Med B 27: 382-397.

Soe AK, Pomroy WE 1992. New species of Eimeria (Apicomplexa: Eimeriidae) from the domesticated goat Capra hircus in New Zealand. Syst Parasitol 23: $195-202$.

Vercruysse J 1982. The coccidia of sheep and goats in Senegal. Vet Parasitol 10: 297-306. 